Article

\title{
Integrating Biodiversity and Ecosystem Services in the Post-2015 Development Agenda: Goal Structure, Target Areas and Means of Implementation
}

\author{
Paul L. Lucas ${ }^{1, *}$, Marcel T.J. Kok ${ }^{1}$, Måns Nilsson ${ }^{2,3}$ and Rob Alkemade ${ }^{1}$ \\ 1 PBL Netherlands Environment Assessment Agency, Postbus 303, 3720 AH, Bilthoven, \\ The Netherlands; E-Mails: marcel.kok@pbl.nl (M.T.J.K.); rob.alkemade@pbl.nl (R.A.) \\ 2 Stockholm Environment Institute, Linnégatan 87 D, Stockholm 115 23, Sweden; \\ E-Mail: mans.nilsson@sei-international.org
}

3 KTH Royal Institute of Technology, School of Architecture and the Built Environment, Division of Environmental Strategies Research, Drottning Kristinas väg 30, Stockholm 100 44, Sweden

* Author to whom correspondence should be addressed; E-Mail: paul.lucas@pbl.nl;

Tel.: +31-030-274-4549.

Received: 1 November 2013; in revised form: 16 December 2013 / Accepted: 17 December 2013 / Published: 27 December 2013

\begin{abstract}
The United Nations' discussions on defining a new set of post-2015 development goals focus on poverty eradication and sustainable development. Biodiversity and ecosystem services are essential for poverty eradication, which is also one of the foundations of the Strategic Plan for Biodiversity of the Convention on Biological Diversity (CBD). Based on an assessment of current proposals of goals and targets, and a quantitative pathway analysis to meet long term biodiversity and food security goals, this paper discusses how biodiversity and ecosystem services can be integrated into a broad set of goals and targets, and concludes with relevant target areas and means of implementation for which specific targets need to be defined. Furthermore, it responds to the call of the CBD to consider the Strategic Plan for Biodiversity and the related Aichi biodiversity targets in the post-2015 development agenda. The paper's analysis identifies three overlapping but also supplemental ways to integrate biodiversity and ecosystem services in the post-2015 agenda: integrated goals, goals addressing earth system functioning and goals addressing environmental limits. It further concludes seven target areas to be included under the goals to address biodiversity and ecosystem services in the context of food and agriculture: access to food, demand for agricultural products, sustainable intensification, ecosystem fragmentation, protected areas, essential ecosystem services and genetic
\end{abstract}


diversity. The Strategic Plan for Biodiversity provides a good basis for integrating biodiversity and ecosystem services in the post-2015 development agenda. Many Aichi targets address the proposed target areas and the means of implementation discussed, while they need to be complemented with targets that specifically address human well-being, as well as institutions and governance.

Keywords: sustainable development goals; biodiversity; ecosystem services; pathways; Aichi targets

\section{Introduction}

Discussions on how to define, design and implement long-term sustainability goals have taken centre stage in the United Nations with the initiation of the process to prepare for a post-2015 development agenda as a follow-up of the Millennium Development Goals (MDGs) [1], and the process to agree upon a set of Sustainable Development Goals (SDGs) [2]. At the 68th session of the United Nations General Assembly, countries agreed that both processes need to come together and result in a single framework and set of goals by the end of 2015 [3]. This framework should be a universal agenda applicable to all countries, addressing poverty eradication and sustainable development, integrating the social, environmental and economic dimensions of sustainability. This agreement is not uncontested, as especially the development community has major concerns that integrating the poverty agenda with a broader sustainable development agenda may erode the political attention and financial support for poverty reduction.

Nonetheless, integrating the agendas is important because biodiversity and ecosystem services are essential for human well-being and poverty eradication, as they provide important services such as soil fertility, drinking water and fuel wood [4]. Unsustainable resource use can cause biodiversity loss and natural resource degradation, with the poor being disproportionally affected. This is also one of the foundations of the Strategic Plan for Biodiversity of the Convention on Biological Diversity (CBD) [5]. The Strategic plan expresses a 2050 vision on biodiversity, accompanied by five Strategic Goals and 20 targets (the so called Aichi targets, see Appendix A). The 2050 vision addresses the need for sustainable use of all ecosystems, including agro- ecosystems, the conservation of biodiversity and the maintenance of ecosystem services for enhancing human well-being. The underlying goals and targets address the importance of biodiversity and ecosystem services for human health, livelihoods and well-being, and integrate the concept of equity. Furthermore, they address the need for sustainable production and consumption, recognize the need for the mainstreaming of biodiversity, and provide a framework for national action. It therefore comes as no surprise that the CBD and the United Nations Environment Programme (UNEP) called for considering the strategic plan and the related targets in the post-2015 development agenda and in the process of establishing the SDGs [6,7]. This paper explores whether and how the post-2015 development agenda can draw from what is already agreed in the CBD and how the post-2015 development agenda can combine development goals with biodiversity and ecosystem goals and targets. 
The Millennium Development Goals (MDGs) prioritize basic needs in global efforts to reduce poverty. The importance of biodiversity for development is recognized under MDG 7 (ensure environmental sustainability) that includes the CBD 2010 biodiversity target to "reduce biodiversity loss, achieving, by 2010, a significant reduction in the rate of loss" [8]. While this target was not met [9], it also became clear that MDG 7 was fragmented, lacked political voice, and lacked an overarching framework and means to integrate different components of environmental sustainability into the broader development agenda [10]. For biodiversity, this last issue is now more specifically addressed by the CBD's Strategic Plan for Biodiversity. More recently, in the Rio+20 outcome document existing commitments to biodiversity were reaffirmed [2]. However, some noted an increasing marginalization of biodiversity and warned that the emphasis on mainstreaming biodiversity in for example the green economy tends to marginalize conservation issues [11].

Over the last year, a wide range of suggestions and approaches for the post-2015 development agenda have been published, ranging from advancing broad development agendas, to advocating specific issues, and proposing various goals, targets and indicators. However, the strong desire to have a small number of easily understandable goals is difficult to combine with the many headline goals proposed. Therefore, this paper does not intend to come up with yet another proposal for goals and targets, but analyzes current proposals with the aim to provide structure on how biodiversity and ecosystem services could be integrated into a broad set of sustainable development goals. Goals express an ambitious, but specific, commitment, and the setting of goals is more a political process at this stage. Targets are, however, mostly quantified sub-components of broadly defined goals that will contribute to achievement of the goals. The identification of targets is generally informed by analytical work. Therefore, this paper also explores target areas for which specific targets and indicators should be set, and discusses means of implementation that are required to create the necessary conditions for these targets to be achieved. Finally, although the paper does not propose specific targets, it responds to the CBD's and UNEP's call for discussion on how further specification and quantification of the proposed target areas and means of implementation could include or be guided by specific Aichi targets.

The CBD Subsidiary Body for Scientific and Technological Advice analyzed current proposals to provide structure in goal architecture with respect to biodiversity and ecosystem services and to link this to relevant Aichi targets [12]. The research presented here adds to their analysis by including a larger number of existing proposals and by using a quantitative pathways analysis [13] and a framework proposed by Nilsson, et al. [14] to identify and structure specific target areas and means of implementation with respect to food and agriculture in relation to biodiversity and ecosystem services.

Agriculture is one of the key links between biodiversity and ecosystem services on the one side, and human well-being (via food security) on the other, and features prominently in the debate about the post-2015 development agenda. Agriculture depends strongly on ecosystem services such as soil fertility, water retention and pollination. It is important for rural development and hunger eradication, while unsustainable practices increase the pressure on biodiversity and ecosystem services through, for example, habitat loss, eutrophication and land degradation. The agriculture challenge for the post-2015 development agenda includes feeding a larger and wealthier population, contributing to the eradication of poverty and hunger, and becoming more environmentally sustainable [9,13,15]. 
The paper starts with examining the rationale for including ecosystem services and biodiversity in the post-2015 development agenda (Section 2). It continues with evaluating ways in which biodiversity and ecosystem services are included in current proposals for the post-2015 agenda (Section 3). Next, we assess pathways towards eradicating hunger and meeting the 2050 Biodiversity Vision within a broad set of sustainable development goals (Section 4). Based on this analysis, we identify possible target areas and explore means of implementation and the possible contribution the Aichi targets can make (Section 5). We conclude with outlining some relevant choices that lay ahead for including biodiversity and ecosystems in the post-2015 development agenda (Section 6).

\section{The Importance of Biodiversity and Ecosystem Services for Human Well-Being}

It is widely acknowledged that biodiversity underpins ecosystem functioning and that the provisioning of ecosystem services is essential for human well-being [4,16]. At the same time, both poverty and economic development do negatively affect global biodiversity and the provision of important ecosystem goods and services [17]. More food, water and biomass are needed to sustain on-going population growth in especially the poorer parts of the world. Continuing economic growth, including growth of the global middle class, will add to the demand for products like meat, construction timber, bio-energy and paper. When current production and consumption patterns prevail, biodiversity loss and natural resource degradation will continue or accelerate without additional policies $[9,18]$, with the poor being disproportionally affected [4]. Therefore, sustainable use of natural capital and the preservation of biodiversity and ecosystem services are vital for sustainable poverty eradication $[19,20]$.

The CBD defines biodiversity or biological diversity as "the variability among living organisms from all sources including, inter alia, terrestrial, marine and other aquatic ecosystems and the ecological complexes of which they are part; this includes diversity within species, between species and of ecosystems" [9]. This broad definition emphasizes variability and recognizes three main levels of variability and the ecological interactions within ecosystems, while it excludes measures that focus on amounts or quantities, such as biomass or total numbers of species [21].

Ecosystem services include provisioning services such as the production of food, wood, fibres and (drinking) water; regulating services such as the maintenance of soil fertility, pest control, pollination, the prevention of erosion, water retention by soil and vegetation and climate regulation; and cultural services, such as spiritual, aesthetic services and providing space for recreation [4]. These services all depend on functioning ecosystems [16,22]. The capacity of provisioning services from, mainly, agro-ecosystems is often maintained and enhanced by technical means, such as the application of fertilizers, pesticides and soil and water management. The challenge for sustainable agricultural production is to apply technical solutions while avoiding the impairment of other, especially regulating, ecosystem services. Appropriate technical solutions remain difficult, especially for the poor, since they are confronted with a lack of means to provide technical solutions [23-25].

The relationship between biodiversity and ecosystem services is not straightforward. Whether more biodiversity would imply more ecosystem services depends largely on the type of ecosystem service [21]. Biodiversity plays a crucial role in the provision of regulating services; examples include the role of pollinators and a large variety of predator species reducing outbreaks of pests in agricultural fields (e.g., [26]). Furthermore, biodiversity is important to some degree for cultural 
services as, for example, a diverse flora and fauna is appreciated by people, but biodiversity is highly ignored when focusing on the production of agricultural products.

Provisioning services contribute to human well-being, by providing materials such as food, water and energy, while other ecosystem services contribute to non-material aspects of human well-being, including spiritual and aesthetic values and the mere appreciation of the diversity of life itself [27,28]. The demand for and production of food, water and energy play a critical role in the connection between the human well-being and ecosystem services [4]. Lack of sustainable access to food, drinking water and modern energy forms a major part of the global problems of poverty and impacts directly on human well-being [29], while the provision of food, water, and energy becomes more difficult when natural resources are not managed sustainably or degrade due to global environmental change, including climate change, land degradation and water scarcity [4,30,31].

\section{Biodiversity and Ecosystem Services in Current Proposals}

Biodiversity and ecosystem services are addressed in many proposals for goals and targets in the post-2015 development agenda. Table 1 provides an overview of proposals and characterizes them in terms of approach (Column two); the way environmental sustainability is integrated into the goals and targets (Column three); whether and how they include biodiversity and/or ecosystem services in the proposed goals and targets (Column four) and whether they explicitly mention the Aichi targets and to what Aichi targets the proposal implicitly or explicitly refers (Column five). Table 2 gives an overview of goals on food, agriculture, biodiversity and ecosystem services in these proposals.

The proposals are selected by searching the Sustainable Development Goals e-Inventory [32] —an online database that collects proposals on global goals for the post-2015 period-for thematic areas "biodiversity" and "ecosystem services", for the period June 2012 (the month of Rio+20) to June 2013. Of the 71 proposals included in the e-inventory, a total of 21 were tagged under "biodiversity" and 14 under "ecosystem services". Only the nine proposals that address the broad post-2015 development agenda, including goals and targets on both poverty eradication and environmental sustainability, are included in our analysis. Finally, a proposal of the global business community [33] was added, which was missing from the e-inventory. The proposals originate from the UN [34], NGOs [35-38], the scientific community [39-42] and the business community [33], and are all closely linked to the UN post-2015 processes. Although the proposals from the scientific community mostly originate from Western countries' institutes, the proposals from the NGOs and UN related institutions include contributions from both developed and developing countries.

\subsection{Approach}

The proposals can broadly be divided in MDG-based approaches and more comprehensive, multidimensional approaches. MDG-based approaches follow the same logic as the original MDG model, but extend the timeline for achieving the goals or add new goals based on lessons learnt from the MDGs. The more comprehensive, multi-dimensional approaches link to the original SDG idea [2] by moving beyond the MDG model and address the broader issues of sustainable production and consumption. The two MDG-based approaches were published in 2012, before, or shortly after the 
Rio+20 Conference, while most multidimensional approaches appeared in 2013, building on the outcomes of the Rio+20 conference.

Table 1. Current proposals for the post-2015 development agenda that include goals and targets on both poverty eradication and environmental sustainability.

\begin{tabular}{|c|c|c|c|c|c|c|c|c|c|c|}
\hline \multirow[b]{2}{*}{ Proposal $^{1}$} & \multicolumn{2}{|c|}{ Approach } & \multicolumn{3}{|c|}{$\begin{array}{c}\text { Integration of } \\
\text { environmental } \\
\text { sustainability }\end{array}$} & \multicolumn{3}{|c|}{$\begin{array}{c}\text { Inclusion of } \\
\text { biodiversity and } \\
\text { ecosystems }\end{array}$} & \multicolumn{2}{|c|}{$\begin{array}{c}\text { Reference } \\
\text { to Aichi } \\
\text { Targets } \\
\end{array}$} \\
\hline & 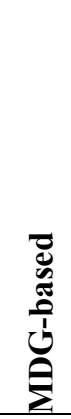 & 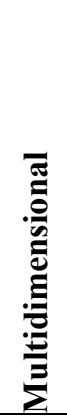 & 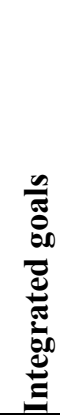 & 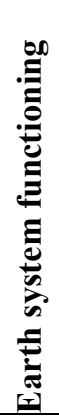 & 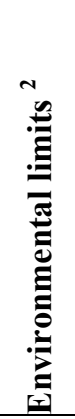 & 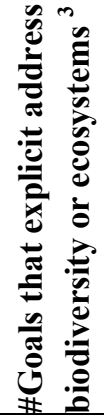 & 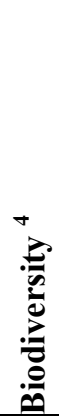 & 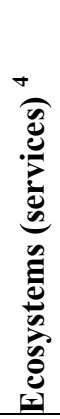 & 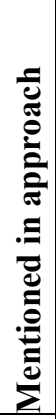 & 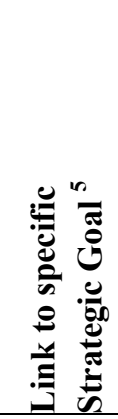 \\
\hline UN-CSD Major Group for Children and Youth [35] & & $\mathrm{X}$ & $\mathrm{X}$ & $\mathrm{X}$ & & $2 / 14$ & $\mathrm{G}$ & $\mathrm{G}$ & & $\mathrm{ABCE}$ \\
\hline Save the children [36] & $\mathrm{X}$ & & & & & $1 / 10$ & $\mathrm{~T}$ & $\mathrm{O}$ & $\mathrm{X}$ & $\mathrm{ABC}$ \\
\hline $\begin{array}{l}\text { Centre for International Governance Innovation and } \\
\text { the Korea Development Institute [39] }\end{array}$ & $\mathrm{X}$ & & & $\mathrm{X}$ & G & $1 / 11$ & $\mathrm{~T}$ & & & - \\
\hline $\begin{array}{l}\text { Campaign for Peoples Goals for Sustainable } \\
\text { Development [37] }\end{array}$ & & $\mathrm{X}$ & $X$ & & & $1 / 10$ & $\mathrm{~T}$ & & & $\mathrm{BCE}$ \\
\hline German Development institute [40] & & $\mathrm{X}$ & $\mathrm{X}$ & $\mathrm{X}$ & & $1 / 7$ & $\mathrm{O}$ & $\mathrm{G}$ & & $\mathrm{BC}$ \\
\hline Griggs et al. [41] in Nature & & $\mathrm{X}$ & $\mathrm{X}$ & $\mathrm{X}$ & FW & $1 / 6$ & $\mathrm{G}$ & $\mathrm{G}$ & $\mathrm{X}$ & BCE \\
\hline $\begin{array}{l}\text { European NGO confederation of relief and } \\
\text { development [38] }\end{array}$ & & $\mathrm{X}$ & $\mathrm{X}$ & $\mathrm{X}$ & FW & $1 / 21$ & $\mathrm{G}$ & $\mathrm{G}$ & & $\mathrm{BCD}$ \\
\hline $\begin{array}{l}\text { High Level Panel of Eminent Persons on the } \\
\text { post-2015 development agenda [34] }\end{array}$ & & $\mathrm{X}$ & $\mathrm{X}$ & $\mathrm{X}$ & & $1 / 12$ & $\mathrm{~T}^{6}$ & $\mathrm{~T}$ & & $\mathrm{ABC}$ \\
\hline Sustainable Development Solutions Network [42] & & $\mathrm{X}$ & $\mathrm{X}$ & $\mathrm{X}$ & G & $1 / 10$ & G & $\mathrm{G}$ & $\mathrm{X}$ & $\mathrm{ABCE}$ \\
\hline United Nations Global Compact [33] & & $\mathrm{X}$ & $\mathrm{X}$ & & & $0 / 10$ & $\mathrm{O}$ & $\mathrm{O}$ & & $\mathrm{B}$ \\
\hline
\end{tabular}

${ }^{1}$ Proposals are presented in chronological order of appearance; ${ }^{2} \mathrm{FW}=$ as overarching framework; $\mathrm{G}=$ mentioned in goal text; ${ }^{3}$ \#goals that explicitly address biodiversity or ecosystems/total \#goals in proposal; ${ }^{4} \mathrm{G}=$ mentioned in goal text; $\mathrm{T}=$ mentioned in target text; $\mathrm{O}=$ mentioned in overall text; ${ }^{5}$ Strategic Goals addressed under goals or targets (see Appendix A for the five Strategic Goals); ${ }^{6}$ Addressed in target 9c as "Safeguard ecosystems, species and genetic diversity".

Table 2. Goals on food, biodiversity and ecosystem services in current proposals for the post-2015 development agenda.

\begin{tabular}{ll}
\hline \multicolumn{1}{c}{ Proposal } & \multicolumn{1}{c}{ Goals on food, biodiversity and ecosystem services } \\
\hline & Address cross-sectoral development areas \\
& Goal 3C: Ensure the health, protection and preservation of oceans, seas \\
UN-CSD Major Group for Children & and marine ecosystems \\
and Youth [35] & Goal 3D: Promote sustainable food-systems \\
& Goal 3E: Forests and Biodiversity \\
\hline
\end{tabular}


Table 2. Cont.

\begin{tabular}{|c|c|}
\hline Proposal & Goals on food, biodiversity and ecosystem services \\
\hline Save the children [36] & $\begin{array}{l}\text { Goal 2: By } 2030 \text { we will eradicate hunger, halve stunting, and ensure } \\
\text { universal access to sustainable food, water and sanitation } \\
\text { Goal 9: By } 2030 \text { we will have a sustainable, healthy and resilient } \\
\text { environment for all }\end{array}$ \\
\hline $\begin{array}{l}\text { Centre for International Governance } \\
\text { Innovation and the Korea } \\
\text { Development Institute [39] }\end{array}$ & $\begin{array}{l}\text { Goal 2: Sufficient Food and Water for Active Living } \\
\text { Goal 10: Sustainable Management of the Biosphere, enabling people } \\
\text { and planet to thrive together }\end{array}$ \\
\hline $\begin{array}{l}\text { Campaign for Peoples Goals for } \\
\text { Sustainable Development [37] }\end{array}$ & $\begin{array}{l}\text { Food sovereignty } \\
\text { Climate justice and environmental sustainability }\end{array}$ \\
\hline German Development institute [40] & $\begin{array}{l}\text { Food security for all } \\
\text { Earth system security }\end{array}$ \\
\hline Griggs et al. [41] in Nature & $\begin{array}{l}\text { Goal 2: Sustainable food security } \\
\text { Goal 5: Healthy and productive ecosystems }\end{array}$ \\
\hline $\begin{array}{l}\text { European NGO confederation of relief } \\
\text { and development [38] }\end{array}$ & $\begin{array}{l}\text { Goal 3: Adequate food and a nutritious diet for all through equitable } \\
\text { and sustainable food production systems } \\
\text { Goal 5: Liveable habitats which are socially, economically and } \\
\text { environmentally sustainable } \\
\text { Goal 13: Equitable access to natural resources } \\
\text { Goal 14: Biodiversity and ecosystem services maintained and restored }\end{array}$ \\
\hline $\begin{array}{l}\text { High Level Panel of Eminent Persons on } \\
\text { the post-2015 development agenda [34] }\end{array}$ & $\begin{array}{l}\text { Goal 5: Ensure Food Security and Good Nutrition } \\
\text { Goal 9: Manage Natural Resource Assets Sustainably }\end{array}$ \\
\hline $\begin{array}{l}\text { Sustainable Development Solutions } \\
\text { Network [42] }\end{array}$ & $\begin{array}{l}\text { Goal 1: End extreme poverty, including hunger } \\
\text { Goal 2: Achieve development within planetary boundaries } \\
\text { Goal 6: Improve agriculture systems and raise rural prosperity } \\
\text { Goal 9: secure ecosystems and biodiversity, and ensure good } \\
\text { management of water and other natural resources }\end{array}$ \\
\hline United Nations Global Compact [33] & $\begin{array}{l}\text { Goal 5:Good nutrition for all through sustainable food and agricultural } \\
\text { systems }\end{array}$ \\
\hline
\end{tabular}

\subsection{Integration of Environmental Sustainability}

The proposals present different views on how to address environmental sustainability. Three views can be distinguished: (1) separate or integrated goals on poverty eradication and environmental sustainability; (2) goals that address the earth system functioning; and (3) goals that address natural resource limits or environmental limits (see also [43]). Current proposals reflect a specific view or a combination of them.

Generally, poverty and environmental issues could be addressed either as separate or as integrated goals or targets. In the context of biodiversity and ecosystem services, the direct link with poverty relates to provisioning and cultural services. Separate goals or targets resemble closely the MDGs, with MDGs 1-6 addressing poverty eradication and MDG 7 addressing environmental sustainability. Integrated goals and targets can be created by mainstreaming the environment in sustainable development through integration of the three sustainability domains in a single goal or in individual targets $[7,12,40,44]$. Examples of integrated goals are the UN Secretary Generals proposals of 
"Sustainable energy for all" (SE4ALL; [45]) and the "Zero hunger challenge" [46]. Most approaches propose integrated goals and/or targets on food security or hunger and agricultural sustainability, while SDSN [42] proposes integrated goals and/or targets on poverty and hunger, and on sustainable food production and economic development.

Along with the separate or integrated goals, several approaches also add goals to guarantee the basic functions of the earth system $[12,40]$. Such goals do not directly relate to the environment-development connections but address biodiversity itself and the supporting ecosystem services, and as such relate to this connection indirectly. Such goals are similar to MDG 7 on environmental sustainability and are included in seven proposals, mostly parallel to integrated goals on food, water and energy. The proposals address earth system functioning through (sustainable) management of biodiversity and ecosystems [34,39,41], secure ecosystems and biodiversity [42], earth system security [40], and/or conservation and restoration of biodiversity and ecosystem services [38,41].

Finally, some approaches specifically include natural resource limits or environmental limits [47], either by including the recognition of natural resource limits in specific goals combined with sustainability issues in addressing an enabling environment for development, or through explicit recognition of such limits, i.e., eradicating poverty within planetary boundaries (see also $[48,49]$ ). In the context of biodiversity and ecosystem services, these limits generally relate to regulating services. The concept of resource limits or environmental limits is recognized in four proposals, either as an overarching framework, included as one of the goals, or addressed in the text. For example, CONCORD [38] proposes a set of environmental goals under the header "living within environmental limits", while SDSN [42] proposes a goal to "achieve development within planetary boundaries".

\subsection{Inclusion of Biodiversity and Ecosystems}

All proposals analyzed include reference to biodiversity and/or ecosystems (services). Five out of the 10 proposals selected address them under specific goals, four under specific targets and two include them in the overall text only. Furthermore, when addressed under a goal or target they all refer to the earth system functioning, while two proposals also specifically address the planetary boundaries as a goal. With respect to food and agriculture, and their relationship to biodiversity and ecosystem services, the proposals include a wide range of goals, addressing food security and hunger, sustainable food systems and sustainable agriculture, sustainable management of biodiversity and ecosystem services, and earth system functioning. Targets address food security (including hunger, stunting, wasting and nutrition), food losses and waste, agricultural productivity, sustainable agriculture, ecosystem restoration, and protection of biodiversity and ecosystems.

\subsection{Reference to the Aichi Targets}

Three out of the 10 proposals analyzed specifically mention the Aichi targets being included under a specific goals or target, but none give explicit reference to individual Aichi targets. One proposal is too vague with respect to goals and targets for biodiversity and ecosystem services [38], that it cannot be linked to any of the Strategic Goals. All other proposals address Strategic Goal B (reducing direct pressures and promote sustainable use), especially with respect to sustainable production. Also, Strategic Goal C (safeguarding ecosystems, species and genetic diversity) is addressed in many of the 
proposals, especially with respect to protected areas. Strategic Goal A (mainstreaming biodiversity) and Strategic Goal E (enhancing implementation) are addressed in less than halve the proposals and Strategic Goal D (enhancing the benefits for all) is addressed in only one proposal. No direct link can be found between the kind of approach or the way environmental sustainability is integrated with the Strategic Goals addressed.

\section{Pathways to Eradicate Global Hunger while Avoiding Further Biodiversity Loss}

Integrating biodiversity and ecosystem services within a post-2015 development framework - including food security and agriculture - requires addressing the various interactions between human development and environmental sustainability. Here, we present a pathway analysis to show how hunger can be eradicated and biodiversity loss can be stabilized in the context of a broad range of long term sustainability issues [13]. These pathways can also help to assess the required transformative actions and to translate these into specific goals and targets, being a key challenge [50].

Achieving food security is a crucial pillar of human development. Food security exists "when all people at all times have access to sufficient, safe, nutritious food to maintain a healthy and active life" [51], with avoiding hunger being an important element of food security. Eradication of hunger must be achieved against a backdrop of sharply increasing demand for food, feed and fuel from a growing and wealthier global population. Therefore, increasing access to food for the poorest households, reducing demand for agricultural products for the wealthier part of the global population, reducing losses and waste and increasing global food production are necessary elements of a strategy to achieve global food security in a sustainable manner.

Increasing access to food could be achieved by increasing production to keep overall food prices low and increase availability for all, or by addressing the distribution of food by specifically targeting food prices for the poorest households. Reducing demand for agricultural products includes reduced meat and dairy consumption, reduced food waste, and restricted use of bio-energy for climate change mitigation. Increasing food production can be achieved by increasing the productivity of land and by the conversion of natural habitats to agricultural land, both potentially resulting in biodiversity loss. Adding to the pressure on biodiversity are increasing bio-energy demand for climate change mitigation and energy security, the expansion of urban areas and infrastructure, and the increasing pollution of terrestrial and aquatic systems. Debate is on-going on how agricultural methods need to develop in order to eradicate hunger and at the same time reduce negative externalities of agricultural production [52]. The strategies range from the intensification of existing agricultural areas while reducing external effects, and the imbedding of agricultural production in a multifunctional landscape, making better use of biodiversity and ecosystem services. Both approaches may lead to sustainable intensification of agriculture, but with different consequences for biodiversity and ecosystem services $[53,54]$.

The pathways presented here were designed to achieve a broad set of targets [13] that are based on existing international agreements on environmental and development topics (see also [55]). In a way, the set of goals could be considered as "sustainable development goals"-avant la lettre. The overarching goal with respect to biodiversity can be phrased as "by 2050 eradicate global hunger while avoiding further biodiversity loss". The goal is based on the CBD 2050 vision and the Aichi targets [5] and MDG target 1c "Halve, between 1990 and 2015, the proportion of people who suffer 
from hunger" [56]. The 2050 vision is interpreted as slowing the rate of biodiversity loss until 2030 and bringing it down to zero loss by 2050 (see Figure 1, left panel), while the MDG hunger target is extended to eradicating hunger by 2050 . The hunger and biodiversity targets are accompanied by targets to limit global long-term mean temperature increase to $2{ }^{\circ} \mathrm{C}$, providing universal access to safe drinking water, basic sanitation and modern energy sources, and reducing urban air pollution and fertilizer use. This forced the analysis to take into account synergies and trade-offs with goals in other themes. The trade-offs include limited biofuel use for climate mitigation to avoid competing claims on land and improved fertilizer-use efficiency to reduce nitrogen emissions resulting from agricultural intensification. Synergies include reduced deforestation due to lower fuel-wood demand resulting from the transition to modern energy sources and reduced meat consumption which reduces both biodiversity loss and climate change.

The following three pathways that meet these goals are distinguished:

- Global Technology: Focus on large-scale technologically optimal solutions, such as intensive agriculture, and a high level of international coordination

- Decentralised solutions: Focus on decentralised solutions, such as agriculture that is interwoven with natural corridors and national policies that regulate equitable access to food

- Consumption Change: Focus on changes in human consumption patterns, most notably by limiting meat intake per capita and by ambitious efforts to reduce waste in the agricultural production chain

The analysis is based on a back-casting approach, addressing the level of effort required to achieve the above described set of sustainability goals, taking into account social, economic and technical constraints, and concentrates on the bio-physical changes required to achieve the goals. For the quantification the integrated assessment model IMAGE in combination with related models for the agricultural economy (LEITAP), biodiversity (GLOBIO), human health (GISMO) and climate policy (FAIR) are used [57-61]. These models provide a global overview, while differentiating between world regions.

Figure 1 presents the contribution of different measures for achieving the biodiversity target, taking into account the other targets, including the eradication of hunger. The pathway analysis points to important elements - included to different degrees - to eradicate global hunger and maintain a stable and sufficient food production, while reaching the biodiversity goal [13]: alter demand for agricultural products including consumption change and reduction of losses and waste; increase agricultural efficiency; change agricultural land allocation and management, including fragmentation; and protect the most important ecosystems and their goods and services. The analysis also points to important synergies with other environmental issues, including climate change and nitrogen deposition. Finally, although not shown in Figure 1, improving access to food by specifically targeting food prices for the poorest households decreases the challenges arising from the elements discussed above.

All three pathways eradicate hunger and reach the global biodiversity target, but the use of different strategies to reach them varies significantly. The analysis shows that long term terrestrial biodiversity goals can be met as part of an integrated agenda of land use, food production, hunger and biodiversity protection, that also provides for access to drinking water, sanitation and modern energy while mitigating climate change. It also shows that achieving the long term biodiversity goal constrains the 
development of the agricultural sector and how the eradication of hunger can be achieved. Although this is not the scope of this paper and there are many caveats in the current data set, the analysis gives input for quantitative target setting, including the required rate of agricultural productivity increase and consumption change. It should further be noted that a strategy solely focusing on improving resource efficiency might lead to rebound effects in the economy and more consumption in the long term. However, the strategies presented in the three pathways combine resource efficiency with measures addressing agricultural demand, land-use planning and protected areas that balance out potential rebound effects.

Figure 1. Different pathways to prevent global biodiversity loss [13]. Biodiversity is indicated by the mean species abundance (MSA) of the original species, with a value of $100 \%$ implying that the abundance equals the natural state and $50 \%$ implying the average abundance of the original species deviates by $50 \%$ from the undisturbed state [60].

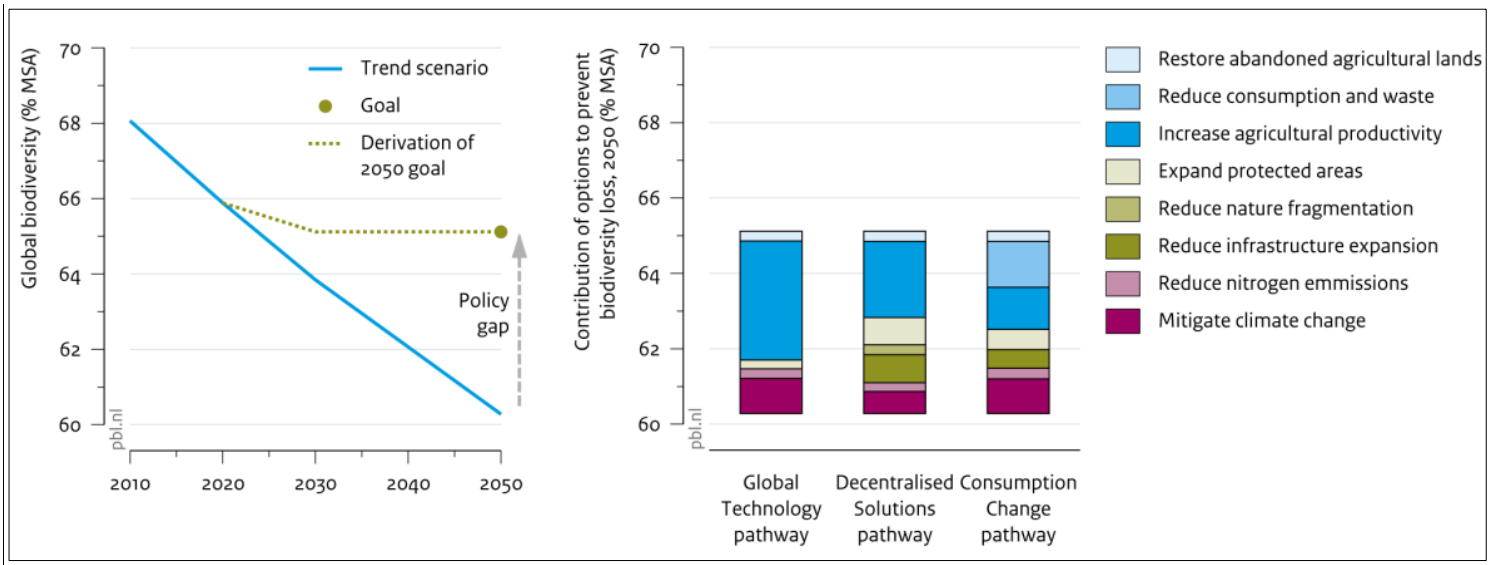

The Consumption Change pathway emphasizes the role of changing consumption patterns as to reduce the demand for food and other products. The Global Technology pathway puts emphasis on increasing yields in large-scale agricultural landscapes and the strict separation of land-use functions. The Decentralised Solutions pathway emphasizes more ecologically oriented agriculture where technology is adapted to smaller-scale agriculture. With respect to access to food, the Global Technology pathway increases access to food by increasing food production and thereby the availability for all. The Decentralised Solutions pathway and the Consumption Change pathway specifically target the food prices for the poorest households. Differences between the Global Technology pathway and the Decentralised Solutions pathway include a lower production intensity and related larger claim on land in the latter, but also an increase in biodiversity and ecosystem services in agricultural fields and surrounding areas, lower fragmentation and reduced emissions of nutrients. Thus, where in the Global Technology pathway biodiversity loss is more concentrated in current agricultural areas, in the Decentralised Solutions pathway biodiversity loss is more spread out, but as a result, biodiversity is much higher in agricultural areas. Furthermore, due to the way access to food is targeted in the Global Technology pathway, food production has to increase more than in the other two pathways, thus increasing the required effort for the other measures to stabilize biodiversity loss. 
The post-2015 agenda provides an opportunity to guide development pathways to benefit both biodiversity and poverty alleviation, considering the many small holders in developing countries, most of whom are poor (and mostly female), and who depend on ecosystems for income, jobs, and food. The pathway analysis stresses the importance of biodiversity and ecosystem services for human well-being and illustrates the necessity of looking at the inter-linkages between food security and biodiversity loss. Furthermore, it shows the importance of sustainable production and consumption and conservation of critical natural areas worldwide. The analysis points at key issues that are necessary to meet long-term goals, interactions between related issues, and the order of magnitude of required efforts (depending also on the contribution of other options). The results can help to indicate the amount of effort required to actually meet the goals and targets.

\section{A Proposal for Target Areas and Means of Implementation}

The pathways' analysis illustrates the importance of promoting sustainable use of natural resources for hunger eradication and addresses the underlying causes of biodiversity loss in an integrated manner. The question is how these inter-linkages and levers of change could be captured in the post-2015 development agenda, making it a universally relevant agenda. To address this question and to further reflect on the goal setting process regarding biodiversity and ecosystems, we use a three-tiered framework for designing SDGs proposed by Nilsson et al. [14] to identify target areas and means of implementation within the overall goals.

The framework puts human wellbeing at the centre, while the resource base and global public goods form the second and third tiers. With this lens, human wellbeing is connected to the surrounding resource base, including the development and sustainable exploitation of natural resources, resource efficiency enhancement, and development and provisioning of man-made resources such as infrastructure. Global public goods, if not managed properly, constrain the development and use of the resource base. While biodiversity and ecosystem services are not in all its dimensions global public goods in the strict economic sense of the definition, several aspects are, including preserving genetic diversity, preventing extinctions and protecting UNESCO World Heritage Sites (see also [62]). Therefore, as will be shown below, targets for biodiversity and ecosystems can be conceived both in the immediate resource base and as global public goods. To enable the delivery of the goals, four nested layers of means of implementations are required, ranging from the fundamental build-up of human capacity and knowledge and institutional and governance frameworks to empower people to draw upon these capacities in their pursuit of wellbeing. This institutional basis in turn provides a source of agency, power and legitimacy for public policy to promote the attainment of goals and will direct financing and investments in implementation.

Table 3 links the Aichi biodiversity targets to the three tiers and the four nested layers of means of implementation. While central to the 2050 Vision and Mission, the Aichi targets do not directly address the first tier, human well-being. The second tier - the resource base - is addressed by the Aichi targets under the Strategic Goals B (reducing direct pressures and promote sustainable use), C (safeguarding ecosystems, species and genetic diversity) and D (enhancing the benefits for all). It should be noted that several of these Aichi targets do relate to constituents or determinants of human well-being that directly depend on, and impact, biodiversity and ecosystems, including Aichi targets 
5-9 on reducing direct pressures and promoting sustainable use, and Aichi target 13 on genetic diversity [12]. The remaining Aichi targets under Strategic Goals B, C and D relate to the maintenance of the planet's life support system, or earth systems' functioning [12]. The third tier-global public goods - is addressed by Aichi target 13 on genetic diversity and Aichi targets 14 and 15 on essential ecosystem services. Aichi targets 4 and 6 address the use of natural resources "well within safe ecological limits", thereby framing the natural resources they address as global public good. Finally, the Aichi targets under Strategic Goals A (mainstreaming biodiversity) and E (enhancing implementation) address the means of implementation, including capacity and knowledge (Aichi targets 1, 18 and 19), public policy (Aichi targets 2-4, 16 and 17) and investment and finance (Aichi target 20). There is no Aichi target that addresses enabling conditions that relate to institutions and governance.

Table 3. The Aichi targets linked to the three tiers and four nested means of implementation.

\begin{tabular}{lccccccc}
\hline & \multicolumn{3}{c}{ Three tiers } & \multicolumn{5}{c}{ Means of implementation } \\
& $\begin{array}{c}\text { Human } \\
\text { well-being }\end{array}$ & $\begin{array}{c}\text { Resource } \\
\text { base }\end{array}$ & $\begin{array}{c}\text { Global } \\
\text { public } \\
\text { goods }\end{array}$ & $\begin{array}{c}\text { Capacity } \\
\text { and } \\
\text { knowledge }\end{array}$ & $\begin{array}{c}\text { Institutions } \\
\text { and } \\
\text { governance }\end{array}$ & $\begin{array}{c}\text { Public } \\
\text { policy }\end{array}$ & $\begin{array}{c}\text { Investment } \\
\text { and } \\
\text { finance }\end{array}$ \\
\hline Strategic Goal A & & $(4)$ & 1 & & $2-4$ & \\
\hline Strategic Goal B & $5-10$ & $(6)$ & & & 16 & \\
\hline Strategic Goal C & 11,12 & 13 & & & 17 & 20 \\
\hline Strategic Goal D & & 14,15 & & 18,19 & & \\
\hline Strategic Goal E & & & & & & \\
\hline
\end{tabular}

\subsection{Target Areas}

The analysis of Section 4 points towards key issues that are necessary to meet long-term goals with respect to food security and agriculture in the context of biodiversity and ecosystem services. These outcomes can be a basis for identifying target areas within the overall set of goals, to be included in the post-2015 development agenda, to address both future food security and limiting global biodiversity loss. The issues are also included in several of the current proposals for the post-2015 development agenda that are analyzed in Section 3.

Based on the analysis of current proposals of Section 3 and the pathway analysis of Section 4, Figure 2 presents an overview of relevant target areas-structured for the three tiers-to integrate biodiversity and ecosystem services, in the context of food and agriculture in the post-2015 development agenda. The target areas are further linked to relevant CBD Strategic Goals and Aichi targets using the summary in Table 3.

The first tier-human well-being - includes target areas on access to food and on demand for agricultural products, including consumption changes and reducing losses and waste. As already concluded, the Strategic Goals do not include Aichi targets that directly address human well-being. The second tier - the resource base-includes target areas on sustainable intensification, ecosystem fragmentation and protected areas. Most Aichi targets under the Strategic Goals B and C address the resource base. Target area $2 \mathrm{a}$ on sustainable intensification of agriculture can mostly benefit from specific Aichi targets under Strategic Goal B on sustainable production (Aichi targets 4 and 6-9). 
Target area $2 \mathrm{~b}$ on ecosystem fragmentation can benefit from Aichi target 5 on habitat loss, while target area $2 \mathrm{c}$ on protected areas can benefit from the Aichi targets under Goal $\mathrm{C}$ on safeguarding ecosystems, species and genetic diversity (Aichi targets 11 and 12). The pathway analysis does not directly address the third tier, global public goods. However, this tier could be addressed by targets regarding earth system functioning and/or by including targets on environmental limits. The first option - earth system functioning - includes targets on essential ecosystem services (Aichi targets 14 and 15), and targets on genetic diversity (Aichi target 13). The second option-environmental limits — could be addressed by Aichi targets 4 and 6 .

Figure 2. Target areas for biodiversity and ecosystem services in the post-2015 development agenda, with a focus on food and agriculture.

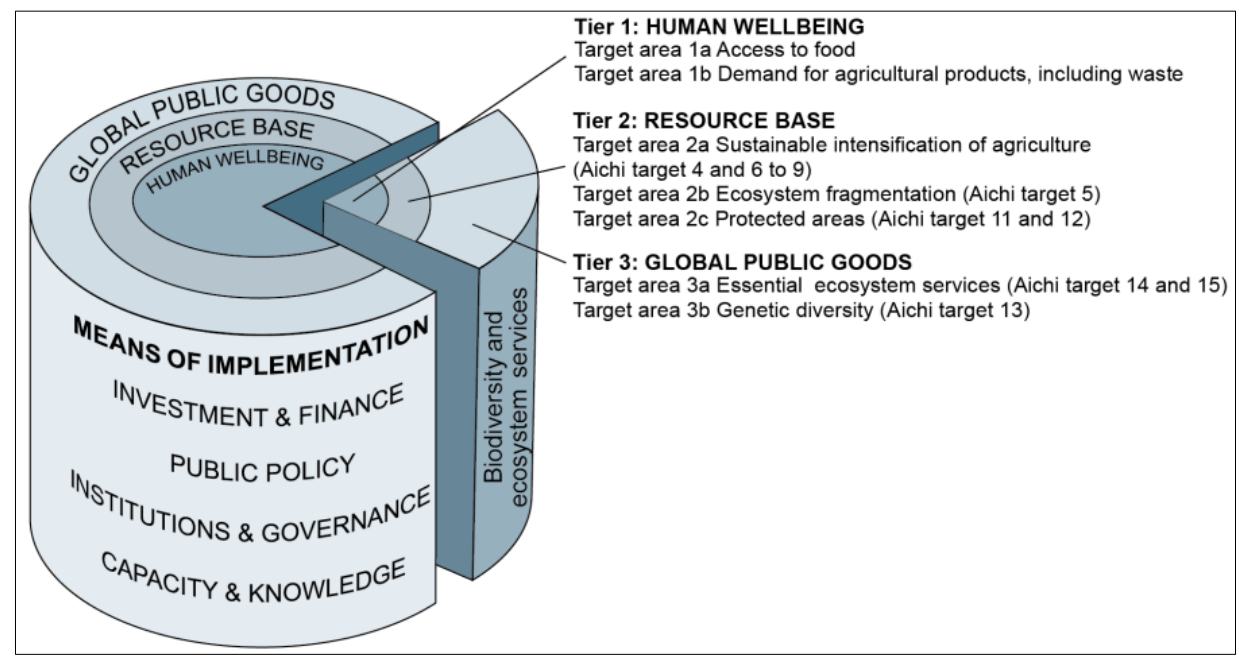

Source: Adapted from Nilsson, et al. [62].

The question of whether the proposed target areas should be part of a headline goal or incorporated into other goals is a critical discussion. Experience with the MDGs suggests that a separate goal on environmental sustainability is not conducive to an integrated approach on poverty eradication and sustainability development. How to deal with these inter-linkages in a pragmatic way is not clear. As discussed in Section 3, possibilities for goal architecture include separate or integrated goals, goals addressing the earth system functioning and goals addressing environmental limits and resource limits. As these three options are partly overlapping but also supplemental, a mixed approach might also be considered, where an integrated goal on food security and sustainable use is complemented with a headline goal that addresses the earth system functioning and/or resource limits and environmental limits. The integrated goal then includes the proposed target areas grouped under human well-being and the resource base, while the headline goal specifically includes the target areas that are grouped under global public goods. Such an approach is applied in many of the recent proposals [35,38,40-42].

It should be noted that besides food and agriculture there are many other thematic areas to which biodiversity and ecosystem services are related, including water, oceans, energy, climate, forests, health, etc. [4]. Although some of these themes might be included under the third tier-global public goods, addressing essential ecosystem services and genetic diversity - most require additional target areas. Furthermore, cultural ecosystem services are not addressed in the analysis, while they are very relevant for human well-being, both in rich and poor countries [17]. A third omission is the role of 
biodiversity in the provision of micro-nutrients as an important part of food security [63,64]. On all these issues there is a long strand of literature, which should be taken into account when designing the full set of goals and targets. Nevertheless, the seven target areas included in Figure 2 provide a basis for this. Several target areas, especially those addressing access and sustainable intensification, are also applicable to other themes beyond food security and agriculture, especially energy and water.

\subsection{Means of Implementation-Enabling Conditions for Delivery}

It can often be difficult to establish targets that can be measured and monitored for complex goals such as alternative consumption patterns or sustainable intensification of agriculture. When ultimate goals are hard to measure, one can monitor accomplishments within the means of implementation instead, as the necessary enabling conditions for achieving the goals [14]. Here, the Strategic Goals and Aichi targets may offer potential, as several means of implementation are actually encapsulated in Strategic Goals A (mainstreaming biodiversity) and E (enhancing implementation). Generally, goals and targets on means of implementation are qualitative in nature and concern the implementation of certain measures according to a certain time table. They may be disaggregated as interim targets over time, into a number of steps of preparation and implementation. Below are some illustrative examples.

Building capacity and knowledge is the most fundamental means. Here, targets could be set for building capacities for data collection and monitoring, performance measurement, and organized knowledge exchange. These issues are in fact addressed by Aichi target 1 on creating awareness and Aichi targets 17-19 on traditional and biodiversity knowledge. The issue of knowledge exchange is particularly salient: often it is not a lack of data that is the main problem, but the tendency to isolate and hold on to data, and interpret it with a narrow organizational mandate and frame. Because of its place-based character in biodiversity and ecosystems, the issue of local knowledge systems, including indigenous knowledge, is especially relevant. The recently established IPBES that will serve the science-policy interface will need to play an important role in, particularly, broader constituencies in key sectors like agriculture, forestry and fisheries and across different scales (from local to international). Implementation would not necessarily be national in scale, but would rather reflect the build-up of local to national to international and interagency knowledge systems. In addition to expert knowledge systems, a particular field of intervention is to enhance the knowledge base among citizens about food consumption choices and their impacts on biodiversity.

Enabling institutions and governance is the next level of implementation. Here, focus could be on the establishment of rule systems for agriculture, forestry and food production. Such aspects are not included under the Aichi targets. The emerging trend of business and biodiversity may provide a good entry point to establish new normative, institutional and governance frameworks that go beyond traditional governmental policies. Examples include systems that limit the use of certain crops and inputs in certain vulnerable zones as well as direct land use control through zoning and permitting. Integrated land-use planning is required, where biodiversity and ecosystem services are taken into account. Here, landscape approaches could provide an important perspective to bring together food production, water use and nature conservation at higher levels of aggregation, to develop institutional mechanisms that are able to deal with the many competing claims on the land [65]. Biodiversity 
concerns may be better incorporated in these schemes and much more attention is needed for the impacts of these schemes on ultimate development goals, as discussed in the previous section.

Establishing public policy frameworks involves a range of possibilities, to be designed and tailored according to what is effective and viable in each jurisdiction. This issue is partly covered under Strategic Goal A on mainstreaming biodiversity and addressed by Aichi target 16 on Access and Benefit Sharing (ABS) and Aichi target 17 on National Biodiversity Strategy and Action Plans (NBSAPs). Within the CBD the NBSAPs are an important step towards action on the national level. While it is recognized that these strategies should contribute to the mainstreaming of biodiversity in other sectors (including agriculture), a review of national challenges and opportunities of implementing the NBSAPs highlights mainstreaming and integration of biodiversity into other sectors as one of the major challenges [66]. Policy measures may include, for instance, the support of voluntary certification schemes by private actors to go beyond legally required standards or mandatory sustainability criteria for food, forest and bioenergy to provide a level playing field. Private labeling schemes can — also on a voluntary basis - play a role in ensuring the sustainability of biotic supply chains in providing direction to producers, traders and consumers. Finally, economic instruments could include crop support or investment support for specific conversion systems as well as payments for ecosystem services.

Mobilizing investment and finance, traditionally the means of implementation that get (by far) the most attention in UN talks, is addressed under Aichi target 20 on resource mobilization. The projected global investment needs to meet the full set of Aichi targets are estimated to be in the order of US\$150-440 billion per year [67], while currently US\$51.5-53.4 billion is allocated annually [68]. While additional budgets for biodiversity conservation may be hard to achieve as part of innovative finance mechanisms, sectoral resource mobilization may be a possible alternative [69]. As the link between biodiversity, ecosystems and food security can be established, ODA funding should be possible, and if biodiversity is linked with deforestation/REDD+, it can be supported as a co-benefit of climate mitigation. However, safeguard rules for the finance need to be set up so that REDD+ efforts are coherent with biodiversity objectives.

\section{Conclusions}

This paper has analyzed how current proposals for the post-2015 development agenda and the SDGs address biodiversity and ecosystem services in relation to agriculture and food security. Furthermore, it presents a pathway analysis that addresses goals and targets on food security and biodiversity in the context of a broad range of other long term sustainability issues. The analyses are used for goal structuring, to propose target areas, to discuss means of implementation and to relate these to the Aichi targets, all as part of the aim to integrate biodiversity and ecosystem services in the post-2015 development agenda:

- Goal structuring. Whether biodiversity should be a headline goal or incorporated into other goals is a critical discussion. The analysis of current proposals identifies three ways for integrating biodiversity and ecosystem services in the goals and targets of the post-2015 development agenda: separate or integrated goals, goals addressing the earth system functioning and goals addressing resource limits or environmental limits. To overcome shortcomings of the MDGs, where a separate goal on environmental sustainability was not conducive for an integrated 
approach on poverty eradication and environmental sustainability, a mixed approach might be more desirable. Such an approach complements an integrated goal on food security and sustainable use with a headline goal that addresses the earth system functioning and/or resource limits and environmental limits. Such an approach is also applied in many of the current proposals.

- Target areas. The pathway analysis identifies areas for which it is relevant to set targets under a broad set of goals, largely in line with the goals and targets included in the analyzed proposals. Based on these areas and the analysis of current proposals, we propose seven target areas to be included in the post-2015 development agenda, addressing human well-being via access to food and demand for agricultural products; the resource base via sustainable intensification of agriculture, ecosystem fragmentation and protected areas; and global public goods via essential ecosystem services and genetic diversity. In a next step, these target areas need to be further specified and quantified, and relevant indicators should be selected to assess progress. How specific targets are set will influence the strategy to reach the overarching goal, potentially resulting in markedly different biodiversity states. Therefore, the policy debate around the post-2015 development agenda needs to put the issues that define the pathways at the centre since this is where the main political choices must be made.

- Means of implementation. As biodiversity and ecosystems for human wellbeing and development are complex areas for policy formulation and goals will be inherently difficult to measure and monitor, the target areas need to be supplemented with means of implementation that address structural barriers and create the enabling conditions for the goals to be achieved. Targets addressing these means of implementation are more qualitative in nature. They include human capacity and knowledge, including data collection and monitoring, performance measurement, and organized knowledge exchange. Furthermore, they include institutional and governance frameworks, such as rule systems, to empower people to draw upon these capacities in their pursuit of wellbeing. This institutional basis in turn provides a source of agency, power and legitimacy for public policy to promote the attainment of goals and will direct financing and investments in implementation.

- Aichi targets. The CBD 2050 vision on biodiversity, the five Strategic Goals and the 20 Aichi targets provide a good basis for integrating biodiversity and ecosystem services in the post-2015 development agenda. The further specification and quantification of the proposed target areas and means of implementation could include or be guided by specific Aichi targets. The targets areas grouped under the resource base and global public goods can benefit from specific Aichi targets addressed under Strategic Goals B (reducing direct pressures and promote sustainable use), C (safeguarding ecosystems, species and genetic diversity) and D (enhancing the benefits for all). Human well-being is not directly addressed by the Aichi targets. Thus, if the Aichi targets somehow feed into the post-2015 development agenda, they need to be complemented by targets that specifically link biodiversity and ecosystem services to human well-being, such as food security and hunger. The Aichi target addressed under Strategic Goals A (mainstreaming biodiversity) and $\mathrm{E}$ (enhancing implementation) address important enabling conditions, while to be fully relevant they should be further specified as means of implementation, especially with respect to investment and finance, and complemented by targets that specifically address institutions and governance. 
The suggested target areas and means of implementation integrate key aspects of agricultural land use and food production. However, besides food and agriculture there are many other thematic areas to which biodiversity and ecosystem services are related, including water, energy, and health. Several target areas, especially those addressing access and sustainable intensification, are also applicable to these themes. Therefore, the target areas identified in this paper may not only contribute to an agreement upon connections between different goals; they are also relevant for selecting targets for the other thematic areas that relate to biodiversity and ecosystem services.

\section{Acknowledgments}

This paper was prepared as an input paper for the fourth Global Biodiversity Outlook (GBO4) of the Convention of Biological Diversity (CBD) as part of the PBL project on Biodiversity and Global Governance. Furthermore, the paper benefited strongly from the PBL project on Inclusive Green Growth. We thank Kitty van der Heijden (Dutch representative for the Open Working Group on Sustainable Development Goals) and Stefan van der Esch and Anne Gerdien Prins (PBL) for valuable input and comments on earlier versions of this paper.

\section{Conflicts of Interest}

The authors declare no conflict of interest.

\section{References}

1. United Nations. Keeping the Promise: United to Achieve the Millennium Development Goals, A/65/L.1. Presented at the Sixty-fifth Session of the United Nations General Assembly, New York, NY, USA, 17 September 2010.

2. United Nations. The Future We Want, A/RES/66/288. In Proceedings of the Rio +20 United Nations Conference on Sustainable Development, Rio de Janeiro, Brazil, 20-22 June 2012.

3. United Nations. Outcome Document of the Special Event to Follow Up Efforts Made Towards Achieving the Millennium Development Goals, A/68/L.4. In Proceedings of the Sixty-Eight Session of the United Nations General Assembly, New York, NY, USA, 1 October 2013.

4. Millennium Ecosystem Assessment. Ecosystems and Human Well-being: Synthesis; Island Press: Washington, DC, USA, 2005.

5. Convention on Biological Diversity (CBD). COP 10 Decision X/2: Strategic Plan for Biodiversity 2011-2020; Secretariat of the Convention on Biological Diversity: Nagoya, Japan, 2010. Available online: http://www.cbd.int/decision/cop/default.shtml?id=12268 (accessed on 1 November 2013).

6. Convention on Biological Diversity (CBD). COP 11 Decision XI/22: Biodiversity for Poverty Eradication and Development; Secretariat of the Convention on Biological Diversity: Hyderabad, India, 2012. Available online: https://www.cbd.int/decision/cop/default.shtml?id=13183 (accessed on 1 November 2013).

7. United Nations Environment Programme (UNEP). Embedding the Environment in Sustainable Development Goals; UNEP: Nairobi, Kenya, 2013. 
8. Convention on Biological Diversity (CBD). COP 6 Decision VI/26: Strategic Plan for the Convention on Biological Diversity; Secretariat of the Convention on Biological Diversity: The Hague, The Netherlands, 2002.

9. Convention on Biological Diversity (CBD). Global Biodiversity Outlook 3; Secretariat of the Convention on Biological Diversity: Montréal, QC, Canada, 2010.

10. United Nations Development Group (UNDG). Thematic Paper on MDG 7: Environmental Sustainability; UNDG and MDG Task Force: New York, NY, USA, 2010.

11. Carrière, S.M.; Rodary, E.; Méral, P.; Serpantié, G.; Boisvert, V.; Kull, C.A.; Lestrelin, G.; Lhoutellier, L.; Moizo, B.; Smektala, G.; et al. Rio+20, biodiversity marginalized. Conserv. Lett. 2013, 6, 6-11.

12. Convention on Biological Diversity (CBD). Biodiversity and Sustainable Development-the Relevance of the Strategic Plan for Biodiversity 2011-2020 and the Aichi Biodiversity Targets for the post-2015 Development Agenda and Sustainable Development Goals; Secretariat of the Convention on Biological Diversity: Montréal, QC, Canada, 2013.

13. PBL Netherlands Environmental Assessment Agency. Roads from Rio+20: Pathways to Achieve Global Sustainability Goals by 2050; PBL: Den Haag/Bilthoven, The Netherlands, 2012.

14. Nilsson, M.; Lucas, P.L.; Yoshida, T. Towards an integrated framework for SDGs: Ultimate and enabling goals for the case of energy. Sustainability 2013, 5, 4124-4151.

15. Sustainable Development Solutions Network (SDSN). Solutions for Sustainable Agriculture and Food Systems: Technical Report for the post-2015 Development Agenda; Prepared by the Thematic Group on Sustainable Agriculture and Food Systems of the Sustainable Development Solutions Network; SDSN: Paris, France, New York, NY, USA, 2013.

16. The Economics of Ecosystems and Biodiversity (TEEB). The Economics of Ecosystems and Biodiversity in National and International Policy Making; Earthscan: London, UK, Washington, DC, USA, 2011.

17. Alcamo, J.; Bennett, E.M. Ecosystems and Human Well-being: A Framework for Assessment; Island Press: Washington, DC, USA, 2003.

18. PBL Netherlands Environmental Assessment Agency. Rethinking Global Biodiversity Strategies; PBL: Den Haag/Bilthoven, The Netherlands, 2010.

19. United Nations Environment Programme (UNEP). Global Environment Outlook IV: Environment for Development; United Nations Environment Programme: London, UK, 2007.

20. Sachs, J.D.; Baillie, J.E.M.; Sutherland, W.J.; Armsworth, P.R.; Ash, N.; Beddington, J.; Blackburn, T.M.; Collen, B.; Gardiner, B.; Gaston, K.J.; et al. Biodiversity conservation and the millennium development goals. Science 2009, 325, 1502-1503.

21. Mace, G.M.; Norris, K.; Fitter, A.H. Biodiversity and ecosystem services: A multilayered relationship. Trends Ecol. Evol. 2012, 27, 19-26.

22. De Groot, R.S.; Alkemade, R.; Braat, L.; Hein, L.; Willemen, L. Challenges in integrating the concept of ecosystem services and values in landscape planning, management and decision making. Ecol. Complex. 2010, 7, 260-272.

23. Food and Agriculture Organization of the United Nations (FAO). Save and Grow-A Policymaker's Guide to the Sustainable Intensification of Smallholder Crop Production; FAO: Rome, Italy, 2011. 
24. Foley, J.A.; Ramankutty, N.; Brauman, K.A.; Cassidy, E.S.; Gerber, J.S.; Johnston, M.; Mueller, N.D.; O’Connell, C.; Ray, D.K.; West, P.C.; et al. Solutions for a cultivated planet. Nature 2011, 478, 337-342.

25. Food and Agriculture Organization of the United Nations (FAO); Centre for Indigenous Peoples' Nutrition and Environment (CINE). Indigenous Peoples' Food Systems: The Many Dimensions of Culture, Diversity and Environment for Nutrition and Health; FAO/CINE: Rome, Italy, 2009.

26. Cardinale, B.J.; Duffy, J.E.; Gonzalez, A.; Hooper, D.U.; Perrings, C.; Venail, P.; Narwani, A.; Mace, G.M.; Tilman, D.; Wardle, D.A.; et al. Biodiversity loss and its impact on humanity. Nature 2012, 486, 59-67.

27. Butler, C.D.; Oluoch-Kosura, W. Linking future ecosystem services and future human well-being. Ecol. Soc. 2006, 11, 30.

28. Nelson, E.; Cameron, D.R.; Regetz, J.; Polasky, S.; Daily, G.C. Terrestrial Biodiversity. In Natural Capital, Theory \& Practice of Mapping Ecosystem Services; Kareiva, P., Tallis, H., Ricketts, T., Daily, G.C., Polasky, S., Eds.; Oxford University Press: New York, NY, USA, 2011.

29. PBL Netherlands Environmental Assessment Agency. Beyond 2015: Long-Term Development and the Millennium Development Goals; Report No. 550025004; PBL: Den Haag/Bilthoven, The Netherlands, 2009.

30. Intergovernmental Panel on Climate Change (IPCC). Impacts, Adaptation and Vulnerability; Cambridge University Press: Cambridge, UK, 2007.

31. United Nations Environment Programme (UNEP). Global Environmental Outlook V.; UNEP: Nairobi, Kenya, 2012.

32. Stakeholder Forum, Sustainable Development Goals e-Inventory. Available online: http://www.sdgseinventory.org/ (accessed on 1 Nobember 2013).

33. United Nations Global Compact (UNGC). Corporate Sustainability and the United Nations Post-2015 Development Agenda: Perspectives from UN Global Compact Participants on Global Priorities and How to Engage Business Towards Sustainable Development Goals; UNGC: New York, NY, USA, 2013.

34. United Nations. A New Global Partnership: Eradicating Poverty and Transform Economies through Sustainable Development; The Report of the High-Level Panel of Eminent Persons on the Post-2015 Development Agenda; United Nations Publications: New York, NY, USA, 2013.

35. UN-CSD Major Group for Children and Youth (MGCY). Proposal on Sustainable Development Goals; MGCY: New York, NY, USA, 2012.

36. Save the Children. Ending Poverty in Our Generation: Save the Children's Vision for a Post-2015 Framework; Save the Children: London, UK, 2012.

37. Campaign for People's Goals for Sustainable Development (CPGSD). Our World. Our Future. Our Goals. Campaign for People's Goals for Sustainable Development; CPGSD: Quezon City, Philippines, 2012.

38. The European NGO Confederation for Relief and Development (CONCORD). Putting People and Planet First: Business as Usual Is Not An Option! CONCORD: Brussels, Belgium, 2013.

39. Bates-eamer, N.; Carin, B.; Lee, M.H.; Lim, W.; Kapila, M. Post-2015 Development Agenda: Goals, Targets and Indicators; The Centre for International Governance Innovation (CIGI) and the Korea Development Institute (KDI): Waterloo, ON, Canada, Seoul, Korea, 2012. 
40. Boltz, F.; Turner, W.R.; Larsen, F.W.; Scholz, I.; Guarín, A. Post 2015: Reconsidering Sustainable Development Goals: Is the Environment Merely a Dimension? German Development Institute (DIE): Bonn, Germany, 2013.

41. Griggs, D.; Stafford-Smith, M.; Gaffney, O.; Rockstrom, J.; Ohman, M.C.; Shyamsundar, P.; Steffen, W.; Glaser, G.; Kanie, N.; Noble, I. Sustainable development goals for people and planet. Nature 2013, 495, 305-307.

42. Sustainable Development Solutions Network (SDSN). An Action Agenda for Sustainable Development: Report for the UN Secretary-General; SDSN: Paris, France, New York, NY, USA, 2013.

43. Melamed, C.; Ladd, P. How to Build Sustainable Development Goals: Integrating Human Development and Environmental Sustainability in a New Global Agenda; Overseas Development Institute (ODI): London, UK, 2013.

44. Melamed, C.; Scott, A.; Mitchel, T. Separated at Birth, Reunited in Rio? A Roadmap to Bring Environment and Development Back Together; Overseas Development Institute (ODI): London, UK, 2012.

45. Advisory Group on Energy and Climate Change (AGECC). Energy for a Sustainable Future. Summary Report and Recommendations; The Secretary-General's Advisory Group on Energy and Climate Change: New York, NY, USA, 2010.

46. United Nations. Ban Ki-moon's remarks at the launch of the Zero Hunger Challenge. UN News, 21 June 2012. Available online: http://www.un.org/apps/news/infocus/sgspeeches/ statments_full.asp?statID=1580\#.UrNplPTuJIR (accessed on 1 November 2013).

47. Evans, A.; Steven, D. Sustainable Development Goals-A Useful Outcome from Rio+20? New York University Center on International Cooperation: New York, NY, USA, 2012.

48. Rockstrom, J.; Steffen, W.; Noone, K.; Persson, A.; Chapin, F.S.; Lambin, E.F.; Lenton, T.M.; Scheffer, M.; Folke, C.; Schellnhuber, H.J.; et al. A safe operating space for humanity. Nature 2009, 461, 472-475.

49. Raworth, K. A Safe and Just Space for Humanity: Can We Live within the Doughnut? Oxfam International: Oxford, UK, 2011.

50. TST Issue Brief: Biodiversity; CITES, CMS, ITPGR and Ramsar: New York, NY, USA, 2013. Available online: http://sustainabledevelopment.un.org/content/documents/2401TST\%20Issues\% 20Brief\%20Biodiversity_FINAL.pdf (accessed on 1 November 2013).

51. Food and Agriculture Organization of the United Nations (FAO). Rome Declaration on World Food Security and World Food Summit Plan of Action. In Proceedings of Adopted at the World Food Summit, Rome, Italy, 13-17 November 1996; FAO: Rome, Italy, 1996.

52. Godfray, H.C.J.; Beddington, J.R.; Crute, I.R.; Haddad, L.; Lawrence, D.; Muir, J.F.; Pretty, J.; Robinson, S.; Thomas, S.M.; Toulmin, C. Food security: The challenge of feeding 9 billion people. Science 2010, 327, 812-818.

53. Phalan, B.; Onial, M.; Balmford, A.; Green, R.E. Reconciling food production and biodiversity conservation: Land sharing and land sparing compared. Science 2011, 333, 1289-1291.

54. Tittonell, P.; Giller, K.E. When yield gaps are poverty traps: The paradigm of ecological intensification in African smallholder agriculture. Field Crop. Res. 2013, 143, 76-90. 
55. Ozkaynak, B.; Pinter, L.; van Vuuren, D.P.; Bizikova, L.; Christensen, V.; Floerke, M.; Kok, M.T.J.; Lucas, P.L.; Mangalagiu, D.; Alkemade, R.; et al. Scenarios and Sustainability Transformation. In Global Environmental Outlook V; United Nations Environment Programme (UNEP): Nairobi, Kenya, 2012.

56. United Nations. Road Map towards the Implementation of the United Nations Millennium Declaration: Report of the Secretary-General. In Proceedings of the Fifty-sixth session of the General Assembly of the United Nations, New York, NY, USA, 6 September 2001.

57. Van Meijl, H.; van Rheenen, T.; Tabeau, A.; Eickhout, B. The impact of different policy environments on agricultural land use in Europe. Agric. Ecosyst. Environ. 2006, 114, 21-38.

58. Bouwman, A.F.; Kram, T.; Klein Goldewijk, K. Integrated Modelling of Global Environmental Change; An Overview of IMAGE 2.4; Netherlands Environmental Assessment Agency (MNP): Bilthoven, The Netherlands, 2006.

59. Hilderink, H.B.M.; Lucas, P.L. Towards a Global Integrated Sustainability Model; GISMO 1.0 Status Report; PBL Netherlands Environmental Assessment Agency: Den Haag/Bilthoven, The Netherlands, 2008.

60. Alkemade, R.; van Oorschot, M.; Miles, L.; Nellemann, C.; Bakkenes, M.; Ten Brink, B. GLOBIO3: A framework to investigate options for reducing global terrestrial biodiversity loss. Ecosystems 2009, 12, 374-390.

61. Den Elzen, M.G.J.; Lucas, P.L. The FAIR model: A tool to analyse environmental and costs implications of regimes of future commitments. Environ. Model. Assess. 2005, 10, 115-134.

62. Kok, M.T.J.; Brons, J.; Witmer, M. A Global Public Goods Perspective on Environment and Poverty Reduction. Implications for Dutch Foreign Policy; PBL Netherlands Environmental Assessment Agency: Den Haag/Bilthoven, The Netherlands, 2011.

63. The Platform for Agrobiodiversity Research (PAR); Food and Agriculture Organization of the United Nations (FAO). Biodiversity for Food and Agriculture-Contributing to Food Security and Sustainability in a Changing World; PAR/FAO: Rome, Italy, 2011.

64. Burlingame, B.; Dernini, S. Sustainable Diets and Biodiversity-Directions and Solutions for Policy, Research and Action. In Proceedings of the International Symposium Biodiversity and Sustainable Diets United against Hunger, Rome, Italy, 3-5 November 2010.

65. Holmgren, P. A Sustainable Development Goal on Landscapes: Setting the agenda at COP19 in Warsaw. Available online: http://blog.cifor.org/19350/a-sustainable-development-goal-on-landscapessetting-the-agenda-at-cop19-in-warsaw\#.UrNoMfTuJIQ (accessed on 1 November 2013)

66. Chandra, A.; Idrisova, A. Convention on biological diversity: A review of national challenges and opportunities for implementation. Biodivers. Conserv. 2011, 20, 3295-3316.

67. Convention on biological diversity (CBD). Report of the High-Level Panel on Global Assessment of Resources for Implementing the Strategic Plan for Biodiversity 2011-2020; CBD: Montréal, QC, Canada, 2012.

68. Parker, C.; Cranford, M.; Oakes, N.; Leggett, M. The Little Biodiversity Finance Book; Global Canopy Programme: Oxford, UK, 2012.

69. Kettunen, M.; D’Amato, D.; ten Brink, P.; Mazza, L.; Malou, A.; Withana, S. Potential of Sectoral Resource Mobilisation to Implement the Aichi Targets in Developing Countries; Institute for European Environmental Policy (IEEP): Brussels, Belgium, 2013. 


\section{Appendix}

Table A1. The Aichi Biodiversity Targets.

\section{Strategic Goal A: Address the underlying causes of biodiversity loss by mainstreaming biodiversity across government and society}

Target 1 By 2020, at the latest, people are aware of the values of biodiversity and the steps they can take to conserve and use it sustainably.

By 2020, at the latest, biodiversity values have been integrated into national and local

Target 2 development and poverty reduction strategies and planning processes and are being incorporated into national accounting, as appropriate, and reporting systems.

By 2020, at the latest, incentives, including subsidies, harmful to biodiversity are eliminated, phased out or reformed in order to minimize or avoid negative impacts, and positive

Target 3 incentives for the conservation and sustainable use of biodiversity are developed and applied, consistent and in harmony with the Convention and other relevant international obligations, taking into account national socio economic conditions.

By 2020, at the latest, Governments, business and stakeholders at all levels have taken steps

Target 4 to achieve or have implemented plans for sustainable production and consumption and have kept the impacts of use of natural resources well within safe ecological limits.

\section{Strategic Goal B: Reduce the direct pressures on biodiversity and promote sustainable use}

Target 5 By 2020, the rate of loss of all natural habitats, including forests, is at least halved and where feasible brought close to zero, and degradation and fragmentation is significantly reduced.

By 2020 all fish and invertebrate stocks and aquatic plants are managed and harvested sustainably, legally and applying ecosystem based approaches, so that overfishing is

Target 6 avoided, recovery plans and measures are in place for all depleted species, fisheries have no significant adverse impacts on threatened species and vulnerable ecosystems and the impacts of fisheries on stocks, species and ecosystems are within safe ecological limits.

Target 7 By 2020 areas under agriculture, aquaculture and forestry are managed sustainably, ensuring conservation of biodiversity.

Target 8 By 2020, pollution, including from excess nutrients, has been brought to levels that are not detrimental to ecosystem function and biodiversity.

By 2020, invasive alien species and pathways are identified and prioritized, priority species

Target 9 are controlled or eradicated, and measures are in place to manage pathways to prevent their introduction and establishment.

By 2015, the multiple anthropogenic pressures on coral reefs, and other vulnerable

Target 10 ecosystems impacted by climate change or ocean acidification are minimized, so as to maintain their integrity and functioning.

\section{Strategic Goal C: To improve the status of biodiversity by safeguarding ecosystems, species and}

genetic diversity

By 2020, at least 17 percent of terrestrial and inland water, and 10 percent of coastal and marine areas, especially areas of particular importance for biodiversity and ecosystem

Target 11 services, are conserved through effectively and equitably managed, ecologically representative and well-connected systems of protected areas and other effective area-based conservation measures, and integrated into the wider landscapes and seascapes.

Target 12 By 2020 the extinction of known threatened species has been prevented and their conservation status, particularly of those most in decline, has been improved and sustained. 
Table A1. Cont.

Strategic Goal C: To improve the status of biodiversity by safeguarding ecosystems, species and genetic diversity

By 2020, the genetic diversity of cultivated plants and farmed and domesticated animals and

Target 13 of wild relatives, including other socio-economically as well as culturally valuable species, is maintained, and strategies have been developed and implemented for minimizing genetic erosion and safeguarding their genetic diversity.

\section{Strategic Goal D: Enhance the benefits to all from biodiversity and ecosystem services}

By 2020, ecosystems that provide essential services, including services related to water, and

Target 14 contribute to health, livelihoods and well-being, are restored and safeguarded, taking into account the needs of women, indigenous and local communities, and the poor and vulnerable.

By 2020, ecosystem resilience and the contribution of biodiversity to carbon stocks has been

Target 15 enhanced, through conservation and restoration, including restoration of at least 15 per cent of degraded ecosystems, thereby contributing to climate change mitigation and adaptation and to combating desertification.

By 2015, the Nagoya Protocol on Access to Genetic Resources and the Fair and Equitable

Target 16 Sharing of Benefits Arising from their Utilization is in force and operational, consistent with national legislation.

Strategic Goal E: Enhance implementation through participatory planning, knowledge management and capacity building

By 2015 each Party has developed, adopted as a policy instrument, and has commenced

Target 17 implementing an effective, participatory and updated national biodiversity strategy and action plan.

By 2020, the traditional knowledge, innovations and practices of indigenous and local communities relevant for the conservation and sustainable use of biodiversity, and their

Target 18 customary use of biological resources, are respected, subject to national legislation and relevant international obligations, and fully integrated and reflected in the implementation of the Convention with the full and effective participation of indigenous and local communities, at all relevant levels.

By 2020, knowledge, the science base and technologies relating to biodiversity, its values,

Target 19 functioning, status and trends, and the consequences of its loss, are improved, widely shared and transferred, and applied.

By 2020, at the latest, the mobilization of financial resources for effectively implementing the Strategic Plan for Biodiversity 2011-2020 from all sources, and in accordance with the

Target 20 consolidated and agreed process in the Strategy for Resource Mobilization, should increase substantially from the current levels. This target will be subject to changes contingent to resource needs assessments to be developed and reported by Parties.

(C) 2013 by the authors; licensee MDPI, Basel, Switzerland. This article is an open access article distributed under the terms and conditions of the Creative Commons Attribution license (http://creativecommons.org/licenses/by/3.0/). 